\title{
PENGARUH PEMBERIAN RAGI TAPE PADA TEPUNG UBI JALAR DALAM PAKAN TERHADAP BERAT ORGAN PENCERNAAN AYAM BROILER
}

\author{
Melson Kadubu Punggu Watu, Permata Ika hidayati, Enike Dwi Kusumawati \\ Fakultas Peternakan \\ Universitas Kanjuruhan Malang \\ Email: permata@unikama.ac.id
}

\begin{abstract}
Abstrak
Penelitian ini bertujuan mengetahui kombinasi terbaik tepung ubi jalar merah dengan ragi sebagai pakan sinbiotik, yang dicampur ke ransum broiler. Jumlah materi yang digunakan sebanyak 100 ekor ayam broiler. Parameter yang diamati berupa organ pencernaan, yang diamati terdiri dari gizzard (rempela), usus halus, usus besar. Metode penelitian terdiri dari persiapan yaitu membersihkan bagian dalam kandang ataupun lingkungan sekitar kandang dengan menggunakan desinfektan kandang, pemeliharaan ayam broiler selama 35 hari, dan perlakuan pada penelitian menggunakan ransum ayam pedaging yang dicampur tepung ubi jalar dan ragi tape, yang dibedakan menjadi enam macam ransum perlakuan, dengan taraf tepung ubi jalar dan ragi tape yang berbeda-beda. Hasil penelitian kombinasi pemberian tepung ubi jalar merah dengan ragi sebagai sinbiotik tidak memberikan pengaruh nyata terhadap pertambahan bobot organ pencernaan ayam broiler (Gizzard, Usus Halus, Usus Besar). Level pemberian terbaik menunjukkan bahwa berat gizzard terdapat pada P2 = 103 gram, berat usus halus terdapat pada P4 = 106 gram, berat usus besar terdapat pada P2 = 86 gram, masing_masing memperlihatkan sebagai berat yang baik atau unggul dengan berat yang tertinggi dibandingkan dengan berat gizzard yang memiliki berat yang berbeda. Kesimpulan dari hasil penelitian bahwa pemberian perlakuan tidak berpengaruh nyata terhadap berat organ pencernaan ayam broiler.
\end{abstract}

Kata kunci : Tepung Ubi jalar, Ragi, Terhadap Pertumbuhan Berat Organ Ayam Broiler

\section{THE EFFECT OF GIVING YEAST OF TAPE TO SWEET PATATO FLOUR IN THE FEED TO THE WEIGHT OF BROILER CHICKEN DIGESTIVE ORGANS}

\begin{abstract}
The study aims to find out the best combination of red sweet potato flour with yeast as sinbiotic feed which is miked to the broiler ration. The amount of material used is 100 broiler chickens. The parameter that is observed is digestive organs; qizzard, small intestive, large intestive. The methodology of the research is quantitative. It contains of preparation of cleaning the insside of cage or the envivonment around the cage by using disintecting the cage, the maintenance of broiler chicken for 35 days, and the treatment in the research is using broiler rations miked with sweet potato flour and yeast of tape, six kinds of treatment rations, with different levels of sweet potato flour and yeast of tape. The results of the research of the combination of red sweet potato with yeast as a sinbiotic is it does not give significant effect to inccrease of broiler gastrroinstestinal weight (qizzard, intestine, colon). The best level of administration shows that the weight of qizzard was found at $\mathrm{P} 2=103$ gram, in $\mathrm{P} 4=106$ gram, the weight of the large intestine or colon is found ad P2=86 gram, pach of it shows that the good weight or superior weight of the highest compared to the weight of the highest compared to the weight of different weight of qizzards. The conlusion of the research is there is no real effect to broiler disentive organ weight in the treatment.
\end{abstract}

Keyword: Ipomea batatas, yeast, performance, digestive tract, broiler chickens

\section{PENDAHULUAN}

Ayam broiler merupakan ayam ras yang memiliki kemampuan tumbuh cepat sehingga dapat menghasilkan daging dalam waktu yang relatif singkat (5-7 minggu), oleh karena itu daging ayam broiler menjadi peranan penting sebagai sumber protein hewani. 


\section{Jurnal Sains Peternakan}

Vol 6, No 1, Juni 2018, pp: 43-48

ISSN 2579-4450

Saat ini peternakan ayam broiler memiliki prospek usaha yang menjanjikan di Indonesia, mengingat kebutuhan protein asal hewani dari tahun ke tahun mengalami peningkatan. Saat ini peternakan ayam broiler memiliki prospek usaha yang menjanjikan di Indonesia, mengingat kebutuhan protein asal hewani dari tahun ke tahun mengalami peningkatan. Menurut Bahri et al. (2005) protein hewani tersusun dari asam-asam amino yang mudah didegradasi oleh tubuh, bersifat esensial bagi perkembangan dan pertumbuhan tubuh manusia. Kombinasi probiotik dengan prebiotik yang diberikan secara bersamaan disebut sebagai sinbiotik. Beberapa jenis prebiotik yang popular termasuk dalam kelompok oligosakarida yaitu fruktosa, rafinosa, inulin, dan galaktosa. Salah satu jenis kelompok oligosakarida yang dapat dijadikan sebagai sumber prebiotik adalah kelompok gula sederhana seperti rafinosa, maltotriosa yang ditemukan pada ubi jalar. Kelompok oligosakarida seperti rafinosa, stakiosa, dan verbakosa tidak dapat dicerna oleh enzim dalam saluran pencernaan, sehingga memerlukan adanya bantuan mikroba pencerna dalam melakukan proses pencernaan senyawa tersebut, salah satu mikroba tersebut adalah Sacharomyces cervisiae asal ragi tape yang saat ini sering digunakan untuk fermentasi pati dari ubi kayu. Jenis oligosakarida ubi jalar adalah rafinosa sebagai oligosakarida tidak tercerna yang dapat menurunkan timbulnya penyakit kanker usus, hati dan saluran pencernaan (Palmer, 2006). Pemberian ubi jalar yang diolah menjadi tepung dengan penambahan ragi tape dalam ransum sebagai sumber sinbiotik diharapkan meningkatkan konsumsi pakan, pertambahanan bobot badan serta konversi pakan.

Sinbiotik merupakan pengembangan ransum konvensional dengan penggabungan probiotik dan prebiotik (Winarno, 2003) yang diberikan secara bersamaan. Istilah sinbiotik digunakan pada produk yang mengandung probiotik dan prebiotik secara sekaligus dalam satu media. Probiotik adalah mikroorganisme hidup yang diberikan sebagai suplemen makanan yang dengan tujuan memperbaiki kesehatan dan perkembangan mikroflora usus. Winarno (2004) menyatakan probiotik merupakan suatu preparat yang terdiri mikroba hidup, yang dimasukan secara oral kedalam tubuh manusia atau ternak, dengan tujuan memberikan pengaruh positif terhadap manusia atau ternak. berperan dalam memecah oligosakarida tersebut.

Adapun mekanisme kerja probiotik jika diberikan pada ayam akan berkolonisasi di dalam usus, dan selanjutnya dapat dimodifikasi untuk sistem imunisasi/kekebalan hewan inang. Komposisi kimia ubi jalar bervariasi tergantung dari jenis, usia, keadaan tumbuh dan tingkat kematangan. Ubi jalar merupakan sumber energi yang baik dalam bentuk karbohidrat. Ubi jalar mempunyai kandungan air yang cukup tinggi. Sewaktu dipanen, ubi jalar mengandung bahan kering antara $16-40 \%$ dan dari jumlah tersebut sekitar 75 - 


\section{Jurnal Sains Peternakan}

Vol 6, No 1, Juni 2018, pp: 43-48

ISSN 2579-4450

90\% adalah karbohidrat (Sulistiyo, 2006). Sebagian besar karbohidrat pada pati ubi jalar terdapat dalam bentuk pati.

Tujuan dari penelitian ini untuk mengetahui pengaruh pemberian ragi tape pada tepung ubi jalar dalam pakan terhadap berat organ pencernaan ayam broiler yang dihasilkan.

\section{MATERI DAN METODE}

Adapun materi penelitian ini yaitu menggunakan ekor ayam pedaging strain CP 707 dari PT. Charoend Phokphand yang dibagi menjadi enam perlakuan dan tiga ulangan, dengan setiap ulangannya terdiri dari sepuluh ekor. Ayam dipelihara selama 28 hari sebelumnya dilakukan pemeliharaan selama tujuh hari. Sampel ayam yang diambil untuk mengukur peubah organ pencernaan adalah satu ekor untuk setiap ulangan.

Metode yang digunakan dalam penelitian ini adalah metode kualitatif dengan analisis data secara diskriptif, dengan 6 perlakuan dengan 3 ulangan, taraf tepung ubi jalar dan ragi tape yang berbeda-beda,dengan rancangan Acak Lengkap $(R A L)$.

\section{Variabel penelitian}

Organ pencernaan unggas memanjang dari mulut hingga sekum, makanan yang masuk melewati saluran tersebut dan mengalami pencernaan dan penyerapan sampai akhirnya keluar berupa feses.

\section{HASIL DAN PEMBAHASAN}

\section{Presentase Bobot Gizzard}

Gizzard merupakan organ fundamental dalam sistem pencernaan ternak unggas, yang memiliki fungsi mencerna makanan yang masuk. Gizzard memiliki dua pasang otot yang kuat dengan sebuah mukosa yang terdapat didalamnya. Bagian dalam gizzard terdiri dari lapisan kulit yang sangat keras, kuat dan sering ditemukan berisi bebatuan kecil yang berfungsi dalam membantu proses pencernaan. North dan Bell (1990) menyatakan otot gizzard akan kontraksi jika terdapat makanan yang masuk ke dalamnya.

Tabel 1. Rataan Persentase Bobot Gizzard Ayam Broiler (\%) Umur 35 hari

\begin{tabular}{lr}
\hline Perlakuan & Total berat Gizzard \\
\hline P0 & $85 \pm 2,08$ \\
P1 & $95 \pm 0,58$ \\
P2 & $103 \pm 5,13$ \\
P3 & $85 \pm 2,08$
\end{tabular}




\section{Jurnal Sains Peternakan}

Vol 6, No 1, Juni 2018, pp: 43-48

ISSN 2579-4450

\begin{tabular}{lr}
\hline P4 & $101 \pm 2,08$ \\
P5 & $97 \pm 4,62$ \\
P6 & $86 \pm 1,53$
\end{tabular}

Rataan

Rata-rata umur berat gizzard dengan $\mathrm{P} 0=85 \%, \mathrm{P} 1=95 \%, \mathrm{P} 2=103 \%, \mathrm{P} 3=85 \%$, $\mathrm{P} 4=101 \%, \mathrm{P} 5=97 \%$, dan P6 $=86 \%$. Hal ini menunjukkan bahwa berat gizzard pada P2 memperlihatkan sebagai berat yang baik atau unggul dengan berat yang tertinggi dibandingkan dengan berat gizzard yang memiliki berat yang berbeda.

\section{Berat Usus Halus}

Usus halus merupakan pusat terjadinya lipolisis dalam tubuh ayam. Dindingdinding duodenum mensekresikan getah usus dan beberapa enzim pemecah gula yang mencerna pakan yang masuk sehingga, kelarutan dan penyerapan zat-zat makanan di jejunum dan ileum lebih mudah dan semakin meningkat (Anggorodi, 1985).

Tabel 2. Rataan Persentase Berat Usus Halus Umur 35 hari

\begin{tabular}{lr}
\hline Perlakuan & Total berat usus halus (\%) \\
\hline P0 & $94 \pm 0,58$ \\
P1 & $74 \pm 4,04$ \\
P2 & $97 \pm 1,53$ \\
P3 & $86 \pm 1,53$ \\
P4 & $106 \pm 6,11$ \\
P5 & $90 \pm 4$ \\
P6 & $91 \pm 12,10$ \\
\hline Rataan
\end{tabular}

Rata-rata berat usus halus dengan $\mathrm{P} 0=94 \%, \mathrm{P} 1=74 \%, \mathrm{P} 2=97 \%, \mathrm{P} 3=86 \%, \mathrm{P} 4=$ $106 \%$, P5 $=90 \%$, dan P6 $=91 \%$. Hal ini menunjukkan bahwa berat usus halus pada P4 memperlihatkan sebagai berat yang baik atau unggul dengan berat yang tertinggi dibandingkan dengan berat usus halus yang memiliki berat yang berbeda. Hal ini mengindikasikan pada level tersebut kerja dari sinbiotik (kombinasi ragi dengan ubi jalar) lebih optimal dalam memberikan performa terbaik untuk ternak, yang terbukti bobot usus halus lebih tinggi dari perlakuan lainnya. 


\section{Jurnal Sains Peternakan}

Vol 6, No 1, Juni 2018, pp: 43-48

ISSN 2579-4450

\section{Berat Usus Besar}

Usus besar merupakan tempat penyerapan air dengan tujuan meningkatkan kadar air di dalam sel tubuh dan menjaga keseimbangan air ayam broiler (Bell dan Weaver, 2002). Berdasarkan hasil sidik ragam yang telah dilakukan pemberian kombinasi tepung ubi jalar merah ditambah ragi tape kedalam ransum komersial sebagai ransum sinbiotik tidak memberikan pengaruh nyata terhadap persentase bobot dan panjang relatif usus besar.

Tabel 3. Persentase Bobot dan Panjang Usus Besar Umur 35 Hari

\begin{tabular}{lr}
\hline Perlakuan & Rata-rata usus besar(\%) \\
\hline P0 & $85 \pm 2,08$ \\
P1 & $59 \pm 9,02$ \\
P2 & $86 \pm 7,02$ \\
P3 & $78 \pm 7,00$ \\
P4 & $72 \pm 5,29$ \\
P5 & $69 \pm 7,81$ \\
P6 & $67 \pm 5,13$
\end{tabular}

Rataan

Rata-rata berat usus besar dengan $\mathrm{P} 0=85 \%, \mathrm{P} 1=59 \%, \mathrm{P} 2=86 \%, \mathrm{P} 3=78 \%, \mathrm{P} 4=$ $72 \%, \mathrm{P} 5=69 \%$, dan P6 $=67 \%$. Pada P0 yang tidak diberikan simbiotik memperlihatkan hal yang sama dengan perlakuan lain yang diberikan pakan simbiotik menyebabkan karna pemberian pakan simbiotik berada dalam kisaran normal.Hal ini menunjukkan bahwa berat usus besar pada P2 memperlihatkan sebagai berat yang baik atau unggul dengan berat yang tertinggi dibandingkan dengan berat usus besar yang memiliki berat yang berbeda.

\section{KESIMPULAN}

Berdasarkan hasil penelitian dapat disimpulkan bahwa Pemberian perlakuan tidak berpengaruh nyata pada berat organ pencernaan ayam broiler (usus halus, usus besar, dan gizzard).

\section{UCAPAN TERIMA KASIH}

Ucapan terima kasih disampaikan kepada semua pihak terutama Laboratorium Lapang Fakultas Peternakan Universitas Kanjuruhan Malang yang telah banyak membantu sejak persiapan hingga terselenggaranya penelitian ini dengan baik. 


\section{Jurnal Sains Peternakan}

Vol 6, No 1, Juni 2018, pp: 43-48

ISSN 2579-4450

\section{DAFTAR PUSTAKA}

Anggorodi, R. 1985. Ilmu Makanan Ternak Unggas Kemajuan Mutakhir. Universitas Indonesia Press, Jakarta.

Bahri, S., Sani, Y., dan Kusumaningsih, A. 2005. Proses Praproduksi Sebagai Faktor Penting dalam Menghasilkan Produk Ternak yang Aman Untuk Manusia. Jurnal Litbang Pertanian. 24(I): 27-35.

Bell, D. D. \& W. D. Weaver . 2002. Commercial Chicken Meat and Egg Production. 5th Edition.Springer Science plus Business Media, Inc. Spiring Street, New York.

North, M. O \& D. D. Bell. 1990. Commercial Chicken Manual. 4th Edition. Champman dan Hall, New York.

Palmer, J. K. 2006. Carbohydrate in sweet potato dalam R. L. Villareal dan T. D. Griggs (Eds.). Sweet Potato Proceding of The First Internasional Symposium. AVRDC, Taiwan.

Sulistiyo, C.N. 2006. Komposisi Kimia Tepung Ubi Jalar. Fakultas Teknologi Pertanian, Institut Pertanian Bogor.

Winarno, F. G. 2003. Flavor bagi Industri Pangan. Mbrio Press, Bogor.

Winarno, F. G. 2004. Keamanan Pangan. Mbrio Press, Bogor 